\title{
The following Presents to the Library have been received, for which the Society tenders its grateful thanks.
}

1. Acta Academiae Aboensis.

2. American Journal of Mathematics.

3. American Mathematical Munthly.

4. Anais da Faculdade de Sciências do Porto

5. Annales de la Faculté des Sciences de Marseille.

6. Annales de la Faculté des Sciences de l'Université de Toulouse.

7. Annales de la Société Polonaise de Mathématique.

8. Annales Scientifiques de l'Université de Jassy.

-9. Annali di Matematica pura ed applicata.

10. Annali della R. Scuola Normale Superiore di Pisa.

11. Annals of Mathematics.

12. Arkiv för Matematik, Astronomi och Fysik.

13. Bollet tino della Unione Matematica Italiana.

14. Bulletin of the American Mathematical Society.

15. Bulletin de Mathématiques et de Physique de l'École Polytechnique de Bucarest.

16. Bulletin of the Calcutta Mathematical Society.

17. Bulletin de la Société Mathématique de France.

18. Bulletin de la Société Physico-Mathématique de Kasan.

-19. Bulletin de la Société Royale des Sciences de Liége.

20. Bulletin Mathématique de la Société Roumaine des Sciences.

21. Bulletin of the University of Kansas.

22. Bulletin Scientifique de l'Université d'Etat de Kiev.

23. Bulletin de l'Académie des Sciences de l'U.R.S.S.

24. Communications de la Société Mathématique de Kharkow.

25. Comptes Rendus de l'A cadémie des Sciences de l'U.R.S.S.

26. Duke Mathematical Journal.

27. Fundamenta Mathematicae.

28. The Mathematical Gạette.

29. Indagationes Mathematicae.

30. The Indian Physico-Mathematical Journa1.

31. Journal de l'Institut Mathématique de l'Académie des Sciences d'Ukraine.

32. Journal of the Indian Mathematical Society.

33. Journal of Mathematics and Physics, Massachusetts Institute of Technology.

34. Journal of the Mathematical Society of Japan.

35. Matematisk Tidsskrift.

36. Mathematicae Notae.

37. Mémoires de la Société Royale des Sciences de Liége.

38. Memoirs and Proceedings of the Manchester Literary and Philosophical Society.

39. Monatshefte für Mathematik und Physik.

40. Nieuw Archief voor Wiskunde.

41. Nova Acta Regiae Societatis Scientiarum Upsaliensis.

42. Portugaliae Mathematica.

43. Proceedings of the American Mathematical Society.

44. Proceedings of the American Philosophical Society. 
45. Proceedings of the Cambridge Philosophical Society.

46. Proceedings of the Leeds Philosophical and Literary Society.

47. Proceedings of the London Mathematical Society.

48. Proceedings of the National Academy of Sciences.

49. Proceedings of the Nova Scotian Institute of Science.

50. Proceedings of the Royal Society of Edinburgh.

51. Publicaciones del Instituto de Matematicas.

52. Publications de l'Institut Mathématique de l'Université de Strasbourg.

53. Recueil Mathématique (Moscow).

54. Rendiconti del Circolo Matematico di Palermo.

55. Rendiconti del Seminario della Facoltà di Scienze (Cagliari).

56. Rendiconti del Seminario Matematico e Fisico di Milano.

57. Rendiconti del Seminario Matematico (Padova).

58. Rendiconti del Seminario Matematico (Roma).

59. Sankhỹ̃ : The Indian Journal of Statistics.

60. Sitzungsberichte (Wien).

61. The Mathematics Student (Indian Mathematical Society).

62. The Tôhoku Mathematical Journal.

63. Transactions of the Actuarial Society of America.

64. Travaux de l'Institut Physico-Mathématique Stekloff.

65. Verhandlungen der Naturforschenden Gesellschaft in Basel.

66. Vierteljahrsschrift der Naturforschenden Gesellschaft in Zïrich.

67. Wiskundige Opgaven mit de Oplossingen. 